\title{
Effects of crop rotation and rainfall on water erosion on a gentle slope in the hilly loess area, China
}

\author{
Wei Wei ${ }^{\mathrm{a}, *}$, Liding Chen ${ }^{\mathrm{a}}$, Handan Zhang ${ }^{\mathrm{a}, \mathrm{b}}$, Lei Yang ${ }^{\mathrm{a}}$, Yang Yu ${ }^{\mathrm{a}}$, Jin Chen ${ }^{\mathrm{c}}$ \\ a State Key Laboratory of Urban and Regional Ecology, Research Center for Eco-environmental Sciences, Chinese Academy of Sciences, Beijing 100085, China \\ b University of Chinese Academy of Sciences, Beijing 100049, China \\ c Dingxi Institute of Soil and Water Conservation, Dingxi, Gansu 743000, China
}

\section{A R T I C L E I N F O}

\section{Article history:}

Received 9 September 2012

Received in revised form 2 July 2014

Accepted 11 August 2014

Available online 2 September 2014

\section{Keywords:}

Crop rotation

Erosion

Loess Plateau

Rainfall

Runoff

\begin{abstract}
A B S T R A C T
Cultivation on steep land has long been blamed as a major contributor of water erosion in many fragile regions of the world. Soil and water loss from gentle slopes, however, are always subjectively considered less important and are even neglected in practice. In this study, 21 plots including seven crop-rotation types (CRTs) under three different slight gradients $\left(10^{\circ}, 15^{\circ}, 20^{\circ}\right)$, were established in Dingxi, a typical semiarid hilly loess area in China. Eight consecutive years of erosion data under different gentle-slope cultivation conditions were compared and analyzed. The most interesting and key finding is that water erosion remained far higher on slopes with gradients of less than $20^{\circ}$ than the tolerable criterion, even when some CRT measures and field treatments (e.g., contour cultivation, stiletto, minimum tillage, and crop-shrub intercropping) were implemented. Newfield techniques targeting erosion control on gentle slopes should be developed. Secondly, compared with other crop species, potato cultivation under sloping conditions was confirmed to cause the highest soil and water loss and should be strictly forbidden at large scales. Being a major source of income for local farmers, potato plantation under terracing conditions, rather than on slopes, is strongly recommended as the first choice for achieving the double advantages of erosion control and farmer income. Thirdly, water erosion on gentle slopes was reduced significantly when different CRTs coupled with land-closure treatments (e.g., farmland abandonment, leaving artificial grassland under natural succession, and consecutive fallows) were conducted simultaneously. This result confirms that these measures are effective for conserving soil and water, and are feasible in practice. Finally, water erosion depended significantly on the timing and proportion of rainstorms in certain periods. The sensitivity of water erosion to natural rainfall, however, was also dependent on the specific surface status. In summary, a higher occurrence of rainstorms coupled with crops that have poor resistance to erosion (e.g., potato, flax, and wheat) and up-down cultivation will certainly accelerate runoff and erosion on slopes, whereas natural succession without human disturbance or appropriate CRTs with contour farming practices can markedly reduce water erosion rates.
\end{abstract}

(c) 2014 Elsevier B.V. All rights reserved.

\section{Introduction}

Poor land-use systems and extensive cultivation on sloping land are blamed as key contributors to water erosion in many fragile mountainous areas. Such erosion can result in marked reductions in soil fertility and water holding capacity, diminished land productivity, and environmental deterioration (Schiettecatte et al., 2005; Shi et al., 2012; Stavi and Lal, 2011; Wang et al., 2008, 2010). In general, more than $56 \%$ of the world's available farmland is endangered by water erosion in agricultural areas, which accounts for $4.3 \times 10^{6} \mathrm{~km}^{2}$ being eliminated for crop production (Jankauskas and Jankauskiene, 2003). Consequently, this situation seriously threatens the agricultural industry, food security, and the sustainability of ecosystem services (Li et al., 2002; Turkelboom et al., 1997). Therefore, the development of more effective cropping

\footnotetext{
* Corresponding author. Tel./fax: +8610 62918673

E-mail address: weiwei@rcees.ac.cn (W. Wei).
}

systems for fields is important for reducing erosion and protecting the environment (Huang et al., 2003; Li et al., 2002; Shipitalo and Edwards, 1998).

An early and long-lasting cultivation center in ancient China (Wang et al., 2010), the Loess Plateau, which currently suffers from severe drought, erosion, and poverty among farmers, has been regarded as the most environmentally devastated region of the world (Chen et al., 2007; Fu, 1989; Li et al., 2002). The latest data show that the total population in this area has reached $8.74 \times 10^{7}$, nearly $79 \%$ of whom are farmers. Total farmland area exceeds $1.3 \times 10^{5} \mathrm{~km}^{2}$. During the past hundreds of years, local residents and communities cleared huge areas of forests and converted them into sloping farmland to increase the food supply (Chen et al., 2007; Fan et al., 2010). Many marginal areas with slope gradients of more than $25^{\circ}$ were cultivated, which significantly increased the potential risk of water erosion. The total eroded area of the Loess Plateau was once recorded as $4.54 \times 10^{5} \mathrm{~km}^{2}$, of which $74 \%$ was affected by water erosion (YRCC, 1988). Improper 
human activity is estimated to have contributed to more than $46 \%$ of the total erosion in the region (Wang et al., 2010; Zhu et al., 2003). The mean erosion modulus (EM) from farmlands was about $8000 \mathrm{t} / \mathrm{km}^{2} /$ year in the late 1990s (Wei et al., 2007). Consequently, water erosion caused by rainstorms and overland flow on steep slopes has accelerated.

The Chinese central government is well aware of the severity of this problem (He et al., 2007; Chen et al., 2010; Fu et al., 2011). In 1999, the so-called "Grain for Green" project, aimed at water erosion control and environmental improvement, was launched. A key part of this program is the restriction of cultivation on slopes with gradients of more than $25^{\circ}$ and the conversion of huge marginal areas to forest, shrub, or grassland (Chen et al., 2007; Fan et al., 2010). However, total discontinuation of cultivation on relatively steep slopes of less than $25^{\circ}$ or total replacement slopes with terraces was hindered by local food requirements and complex landforms. Thus, large areas of sloping cropland remain and continue to contribute to runoff and sediment yield. For example, Fu et al. (2011) highlighted that zones with gradients from $8^{\circ}$ to $35^{\circ}$ have accounted for $82 \%$ of the total soil loss on the Loess Plateau. The mean EM in areas with gradients ranging from $8^{\circ}$ to $25^{\circ}$ has been approximately $4150 \mathrm{t} / \mathrm{km}^{2} /$ year, far beyond the tolerable EM of $1000 \mathrm{t} / \mathrm{km}^{2} /$ year promulgated by the Ministry of Water Resources (SL190-96). Unfortunately, in this region, less attention has been paid to water erosion related to cultivation on gentle slopes, a circumstance that should be improved with further steps.

The extent of water erosion on sloping arable lands is affected by many characteristics of the ground surface. Crop rotation, tillage practices, and other field management strategies have key effects over time and space (Lafond et al., 2006; Li et al., 2002; Prasuhn, 2012; Wang et al., 2010). Specific crop species also affect soil conservation (Baets et al., 2011; Malik et al., 2000; Singh et al., 1999). For example, fallow land and land with winter cereal crops have been found to be less susceptible to soil erosion than land cropped with potato or maize (Stevens et al., 2009). Crop rotation types (CRTs) with appropriate field treatments such as conservation tillage have been shown to be valid measures for minimizing erosion, improving water use efficiency and soil carbon sequestration, and maintaining high grain yields (Freebairn et al., 1993; Raclot and Albergel, 2006; Thierfelder and Wall, 2009). Additionally, consecutive plant succession without human disturbance can increase water infiltration and reduce erosion potential significantly, thus improving soil attributes and promoting crop productivity (Kellison and Young, 1997; Xu et al., 2008).

Natural rainfall conditions, on the other hand, are a key driver of water erosion in the real world (de Lima and Singh, 2002; Sasal et al., 2010; Wei et al., 2009). The distribution of rain events in many areas results in only a few storms being responsible for the majority of erosion (Wei et al., 2009). A case study in Tunisia also indicated that three storm-induced floods were responsible for half the sediment yield in 1994 and 2002 (Albergel et al., 2005). The amount, intensity, and regime of natural rain events markedly affect the temporal distribution and magnitude of erosion rates, particularly in fragile ecosystems and on sparsely vegetated slopes (Basic et al., 2004; Thomas et al., 2011; Wei et al., 2007). Consequently, studies on the response of water erosion to crop rotation and rainfall are required in the hilly loess area, especially on hillslopes with gradients of $0^{\circ}$ to $25^{\circ}$, where intensified agriculture practices remain in some regions. The combined effects of time-dependent rainfall and the state of fields with respect to cultivated crop, tillage, and soil looseness are important factors in erosion dynamics in any given region (Fiener et al., 2011; Prasuhn, 2012).

In this study, 21 experimental plots with gradients of less than $25^{\circ}$ $\left(10^{\circ}, 15^{\circ}\right.$, and $\left.20^{\circ}\right)$ were established on a rain-fed agricultural catchment in the western part of the Loess Plateau, China. Eight years of consecutive hydrology-erosion data were analyzed. Three specific objectives were expected to be achieved: (1) an analysis of the effect of the features of rainfall on variation in erosion, (2) an assessment of the effects of different crop species and field treatments on runoff and soil erosion, and (3) a determination of the roles of CRSs on water erosion dynamics under gentle-slope conditions.

\section{Materials and methods}

\subsection{Study area}

Field experiments were conducted in a typical semiarid area called the Quanwangou catchment $\left(35^{\circ} 22^{\prime}-35^{\circ} 25^{\prime} \mathrm{N}, 104^{\circ} 31^{\prime}-104^{\circ} 34^{\prime} \mathrm{E}\right)$, which has an area of approximately $9.17 \mathrm{~km}^{2}$, on the Loess Plateau, Dingxi, northwestern China (Fig. 1). Rain-fed agriculture is the dominant industry in this region, which has experienced accelerated soil erosion for many decades (Chen et al., 2007; Fu, 1989; Huang et al., 2005; Wei et al., 2009). The region has a temperate terrestrial climate with warm, humid summers and cold, dry winters. The mean annual precipitation is $415 \mathrm{~mm}$, more than $60 \%$ of which occurs between June and September. The historical highest and lowest annual precipitation amounts are $722 \mathrm{~mm}$ (1967) and $246 \mathrm{~mm}$ (1982), respectively, which indicates that high temporal variation of precipitation occurs through different years. The average annual sunshine, radiation duration, and air temperature are $5.6 \times 10^{9} \mathrm{~J} / \mathrm{m}^{2}, 2500 \mathrm{~h}$, and $6.2{ }^{\circ} \mathrm{C}$, respectively. The mean annual potential evaporation is $1318 \mathrm{~mm}$. Approximately 140 days/year are frost-free.

Based on a local investigation, more than $70 \%$ of the catchment area has been cultivated with a large majority of cereal crops, with which CRTs with leguminous or tuber crops have sometimes been used. The major cultivated crop species are potato (Solanum tuberosum L.), maize (Zea mays L.), flax (Linum usitattissimum L.), and spring wheat (Triticum aestivum Linn.). Potatoes grow well and are planted over large areas. Consequently, Dingxi City is known as the "potato capital" of China. Shrubs and grasses, rather than tree species, are more suitable in this area because of the scarce rainfall and restricted freshwater (Chen et al., 2007). Mesquite species, such as sea buckthorn (Hippophae rhamnoides L.) and Caragana korshinskii, have been planted or sowed as major shrubs, whereas Chinese pine (Pinus tabuliformis Carr.), Chinese arborvitae (Platycladus orientalis L.), and apricot (Prunus armeniaca L.) have been established at the bottom of gullies where better water and nutrient conditions occur. Naturally established and artificially planted grass species include bunge needlegrass (Stipa bungeana Trin.), alfalfa (Medicago sativa L.), sweet clover (Melilotus officinalis L.), and sainfoin (Onobrychis viciaefolia Scop.).

The local loess soil (windblown silt) in the small Gaoquangou catchment remains generally the same. Soil depth ranges from $40 \mathrm{~m}$ to $100 \mathrm{~m}$, and the soil is classified as calcic Cambisol (FAO-UNESCO, 1974). The depth of arable soil varies from $2 \mathrm{~m}$ to $10 \mathrm{~m}$, and soil organic matter is generally less than $10 \mathrm{~g} / \mathrm{kg}$. Soil porosity, $\mathrm{pH}$ value, available nitrogen, and available phosphorus are $48.5 \%$ to $57.3 \%, 7.5$ to 8.6 , $30 \mathrm{mg} / \mathrm{kg}$ to $60 \mathrm{mg} / \mathrm{kg}$, and $1.3 \mathrm{mg} / \mathrm{kg}$ to $2.9 \mathrm{mg} / \mathrm{kg}$, respectively. The mean bulk density of the soil in the top $2 \mathrm{~m}$ of the soil layer is approximately $1.1 \mathrm{~g} / \mathrm{m}^{2}$ to $1.4 \mathrm{~g} / \mathrm{m}^{2}$, which renders it vulnerable to water erosion during severe rainstorms and overland flow. Moreover, the landform of the catchment is fragmented and consists of rugged landscapes, with a gully density of $2.38 \mathrm{~km} / \mathrm{km}^{2}$. Altitude varies from $2056 \mathrm{~m}$ to $2447 \mathrm{~m}$. Ridges, hillslopes, terraces, and gullies cover an area of $6.9 \%, 52.4 \%$, $13.8 \%$, and $26.9 \%$, respectively. Slope gradients of $5^{\circ}, 5-10^{\circ}, 15-25^{\circ}$, $25-35^{\circ}$, and $35-45^{\circ}$ represent $32.3 \%, 38.8 \%, 17.3 \%, 6.1 \%$, and $5.5 \%$ of the landscape, respectively. Large amounts of fertile soil are prone to being washed away, which severely degrades the land.

\subsection{Experimental design}

In this study, 21 experimental plots (Table 1) were established in the middle position of a hillslope within the catchment. The area covered by each bounded plot was $10 \mathrm{~m}^{2}$, width of $2 \mathrm{~m}$ and length of $5 \mathrm{~m}$. For each plot, cement ridges ( $35 \mathrm{~cm}$ above the ground) were constructed at the borders to isolate runoff and sediment 


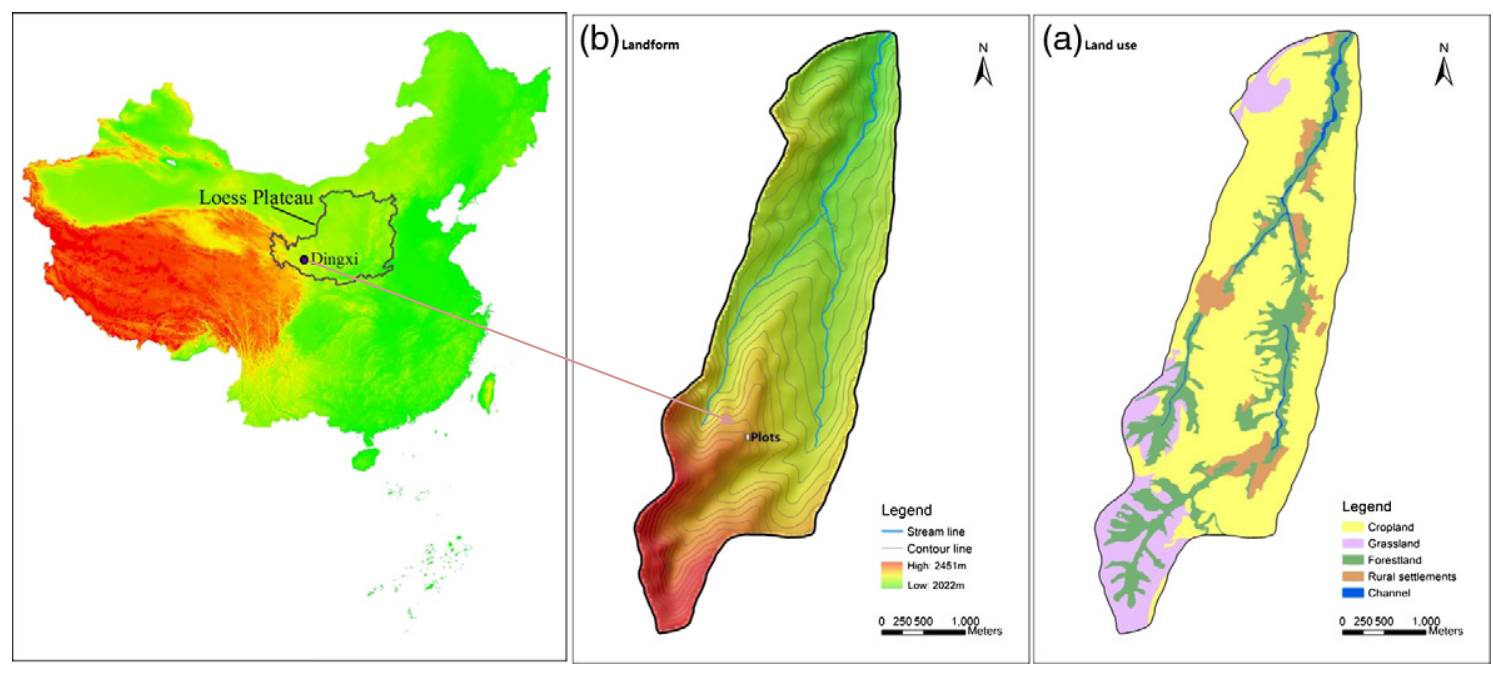

Fig. 1. The location of the study area and experimental plots.

yield. A discharge ditch was created at the top of each plot to prevent soil water lost from the upper side of the area from entering the plot. The 21 plots were all located on a single hillslope to reduce the effects of variation in soil condition and slope position. The plots were oriented parallel to the slope and adjacent to one another, and were separated by a distance $1.5 \mathrm{~m}$. Different CRTs were implemented (Table 1), and related hydrological data including rainfall, runoff, and sediment yield were measured and collected for eight consecutive years.

Seven CRTs with three replications $\left(10^{\circ}, 15^{\circ}\right.$, and $20^{\circ}$ slope gradients) were involved: (CRT-1): potato/haricot/wheat/potato/ pea/wheat/haricot/flax; (CRT-2):wheat/pea/wheat + mini.plough/ flax/fallow/fallow/fallow/fallow; (CRT-3): wheat + seabuckthorn/ flax/pea/wheat + seabuckthorn/haricot/flax/pea/wheat; (CRT-4): flax/potato/haricot/wheat/flax/haricot/potato/pea; (CRT-5): haricot/ wheat + stiletto/potato/pea/wheat/potato/flax/haricot; (CRT-6): pea/ wheat/flax/haricot/potato/pea/wheat/potato; and (CRT-7): E. milvetch/ E. milvetch/E. milvetch/E. milvetch/E. milvetch/E. milvetch/E. milvetch/ E. milvetch. CRT-7 was designed as an important comparison to analyze the effects of crop rotation and plant succession on water erosion rates. Additionally, two major tillage types including up-and-down tillage and contour cultivation were designed before field cultivation (mainly in late April or early May) (Table 1). In the first year, CRT-2 (wheat was planted in this year) and CRT-6 (pea was planted in this year) were cultivated on contours, whereas up-and-down cultivation was implemented in other years with other CRTs. Moreover, minimum tillage was used in CRT-2 during the third year, whereas stiletto was used in CRT-5 during the second year.

\subsection{Data sampling and collection}

An $\mathrm{SJ}_{1}$ auto-siphon rain gauge was established on the hillslope to monitor natural rainfall during the growing season (mainly from May to September), when most erosive rain and soil loss occur. Simultaneously, daily rain events were monitored by an auto-recording rain gauge. The depth, duration, and intensity of each rainfall were recorded and used to calculate key variables, such as maximum intensity and erosivity. A marked $\mathrm{H}$-flume and two volumetric tanks were built at the outlet of each plot to collect runoff and sediment. Specifically, the volume of runoff after each rainfall event was calculated based on the actual water volume in the collector. A $250-\mathrm{ml}$ cylinder was used to collect turbid water and included sediment. The sample was set aside for deposition, followed by filtering, drying, and weighing. EM was calculated based on the procedures described in the following section. The collectors of the experimental plots were cleaned after each measurement in preparation for detection during the next rainfall-runoff event.

\subsection{Mathematical analysis}

In this study, frequency statistical analysis was used to investigate the effects of crop rotation and the variations of crop rotation on runoff and erosion rates. Descriptive analysis was used to depict temporal rainfall features. The runoff coefficient (RC; Eq. (1)) was quantified as runoff divided by rainfall depth, whereas EM (Eq. (2)) was calculated using the amount of sediment divided by the specific area of each experimental plot (Wei et al., 2007). In particular, erosive rainfalls

Table 1

Experimental plots and CRT design.

\begin{tabular}{|c|c|c|c|c|c|c|c|c|c|}
\hline \multirow[t]{2}{*}{ CRT } & \multirow[t]{2}{*}{ Plot number } & \multicolumn{8}{|c|}{ Annual cultivated crop } \\
\hline & & YN-1 & YN-2 & YN-3 & YN-4 & YN-5 & YN-6 & YN-7 & YN-8 \\
\hline CRT-1 & $1-3$ & Potato & Haricot & Wheat & Potato & Pea & Wheat & Haricot & Benne \\
\hline CRT-2 & $4-6$ & Wheat* & Pea & Wheat + M.T. & Benne & Fallow & Fallow & Fallow & Fallow \\
\hline CRT-3 & $7-9$ & Wheat + Sea. & Benne & Pea & Wheat + Sea. & Haricot & Benne & Pea & Wheat \\
\hline CRT-4 & $10-12$ & Benne & Potato & Haricot & Wheat & Benne & Haricot & Potato & Pea \\
\hline CRT-5 & $13-15$ & Haricot & Wheat + Sti. & potato & Pea & Wheat & Potato & Benne & Haricot \\
\hline CRT-6 & $16-18$ & Pea* & Wheat & Benne & Haricot & Potato & Pea & Wheat & Potato \\
\hline CRT-7 & $19-21$ & E. milvetch & E. milvetch & E. milvetch & E. milvetch & E. milvetch & E. milvetch & E. milvetch & E. milvetch \\
\hline
\end{tabular}

Note: Asterisk indicates cultivation on contours (+C.C.), while others (no asterisk) indicate cultivation up-down (+U.D) the slope. YN is year number. 
were recorded and defined as actual rainfall events that caused sediment loss in the plots. Based on this definition, the erosive rainfall depth (ERD) and erosive rainfall times (ERT) can be calculated. Data were analyzed using Statistical Product and Service Solutions (SPSS) 16.0.

$\mathrm{RC}=\left(\sum_{i=1}^{n} \mathrm{SR} / \sum_{i=1}^{n} \mathrm{RD}\right) \times 100 \%$

$\mathrm{EM}=\left(\sum_{i=1}^{n} \mathrm{SY} / \mathrm{PA} * \mathrm{YR}\right) \times 10^{3}$

where RC, SR, RD, EM, SY, PA, and YR refer to runoff coefficient (\%), runoff depth $(\mathrm{cm})$, rainfall depth $(\mathrm{cm})$, erosion modulus $\left(\mathrm{t} / \mathrm{km}^{2} /\right.$ year$)$, sediment yield ( $\mathrm{mg})$, plot area $\left(\mathrm{m}^{2}\right)$, and year, respectively.

\section{Results}

\subsection{Rainfall features and water erosion rates}

Based on local meteorological data, annual rainfall features (including total rainfall depth (TRD), erosive rainfall depth (ERD), average rain intensity (AI), maximum intensity within $30 \mathrm{~min}\left(\mathrm{MI}_{30}\right)$, times of rainfall occurrence, and other key rainfall variables) over the eight observation years were analyzed. The values of $R C$ and $E M$ from the plots were also captured (Table 2).

Table 2 shows that rainfall variables varied markedly across different years. The highest and lowest frequencies of erosive rainfall events appeared in the last year ( 13 times) and the third year ( 6 times), respectively. According to annual TRD, the rainiest years were the third year $(500 \mathrm{~mm})$ and the sixth year $(467 \mathrm{~mm})$, whereas the driest years were the last year (392 $\mathrm{mm}$ ) and the first year (391 mm). Furthermore, the annual ERD exhibited a decline in the order YN-8 (309 mm), YN-7 (288 mm), YN-2 (240 mm), YN-6 (166 mm), YN-1 (141 mm), YN-3 (139 mm), YN-5 (121 mm), and YN-4 (119 mm), where YN represents "year number." $\mathrm{MI}_{30}$ varied from $0.13 \mathrm{~mm} / \mathrm{min}$ to $0.49 \mathrm{~mm} / \mathrm{min}$ and decreased in the orderYN-7, YN-3, YN-2, YN-8, YN-4, YN-5, YN-1, and YN-6.

These data give rise to two basic observations. First, although erosive rainfall events occurred in both dry and wet years, the annual variation of ERD is inconsistent with those of TRD and $\mathrm{MI}_{30}$. The inconsistency indicates that the raininess or dryness of a year has no direct or necessary correlation with the highest or lowest risk of erosion generation. For example, the second driest year (YN-8, $392 \mathrm{~mm}$ )

Table 2

Annual rainfall features and mean water erosion rates.

\begin{tabular}{|c|c|c|c|c|c|c|c|c|c|}
\hline \multirow[t]{2}{*}{ YN } & \multirow[t]{2}{*}{ TRD } & \multirow[t]{2}{*}{ TRT } & \multirow[t]{2}{*}{ ERD } & \multirow[t]{2}{*}{ ERT } & \multicolumn{2}{|l|}{ ERI } & \multirow[t]{2}{*}{ ERD/TRD (\%) } & \multirow[t]{2}{*}{$\mathrm{RC}(\%)$} & \multirow[t]{2}{*}{ EM } \\
\hline & & & & & AI & $\mathrm{MI}_{30}$ & & & \\
\hline YN-1 & 391.1 & 113 & 140.6 & 11 & 0.07 & 0.13 & 35.95 & 20.53 & 4891 \\
\hline YN-2 & 441.9 & 111 & 239.7 & 8 & 0.08 & 0.40 & 54.24 & 24.63 & 7669 \\
\hline YN-3 & 500.1 & 96 & 138.8 & 6 & 0.067 & 0.41 & 27.75 & 24.14 & 7031 \\
\hline YN-4 & 421.6 & 99 & 119.5 & 7 & 0.03 & 0.18 & 28.34 & 18.07 & 6120 \\
\hline YN-5 & 429.6 & 103 & 121.4 & 9 & 0.06 & 0.15 & 28.26 & 18.24 & 5742 \\
\hline YN-6 & 466.9 & 101 & 166 & 9 & 0.05 & 0.11 & 35.55 & 15.73 & 5042 \\
\hline YN-7 & 411.6 & 99 & 287.7 & 12 & 0.17 & 0.49 & 69.90 & 26.29 & 7925 \\
\hline YN-8 & 387.8 & 64 & 309.4 & 13 & 0.09 & 0.27 & 78.97 & 21.25 & 6272 \\
\hline
\end{tabular}

Note: TRD, TRT, ERD, ERT, ERI, AI, MI30, RC, and EM mean total rainfall depth (mm), total rainfall times (non-dimensional), erosive rain depth $(\mathrm{mm})$, erosive rain times (nondimensional), erosive rain intensity $(\mathrm{mm} / \mathrm{min})$, average rain intensity $(\mathrm{mm} / \mathrm{min})$, maximum rain intensity within $30 \mathrm{~min}(\mathrm{~mm} / \mathrm{min})$, runoff coefficient, and erosion modulus ( $\mathrm{t} / \mathrm{km}^{2} /$ year $)$, respectively. had the highest ratio of erosive rain events ( $309 \mathrm{~mm}$ ). Secondly, erosive rainfall events occurred irregularly and torrentially in most cases. The inter-annual distribution and characteristics of natural rainfall events are subject to highly stochastic rules across different years, which may increase the difficulties of accurate prediction of water erosion risk.

The mean annual RC and EM have a similar dynamic role with some key rainfall variables, especially the erosive rain intensity (ERI), including AI and $\mathrm{MI}_{30}$ (Table 2). For example, the highest RC (26.29\%) and EM $\left(7925 \mathrm{t} / \mathrm{km}^{2} /\right.$ year $)$ were observed in YN-7, along with the highest values of $\mathrm{AI}(0.17 \mathrm{~mm} / \mathrm{min})$ and $\mathrm{MI}_{30}(0.49 \mathrm{~mm} / \mathrm{min})$. The lowest RC (15.73\%) and EM (5042 t/ $\mathrm{km}^{2} /$ year), with the same levels of $\mathrm{AI}(0.05 \mathrm{~mm} / \mathrm{min})$ and $\mathrm{MI}_{30}(0.11 \mathrm{~mm} / \mathrm{min})$, occurred in YN-6 (Table 2). Moreover, the annual variations of RC and EM were not always consistent with each other and differed slightly in some years. For instance, the values of RC were $20.5 \%$ (YN-1) $>18.2 \%$ $(\mathrm{YN}-5)>18.0 \%(\mathrm{YN}-4)>15.7 \%(\mathrm{YN}-6)$, whereas values of $\mathrm{EM}$ declined in the order $6120 \mathrm{t} / \mathrm{km}^{2} /$ year $(\mathrm{YN}-4)>5742 \mathrm{t} / \mathrm{km}^{2} /$ year $(\mathrm{YN}-5)>5042 \mathrm{t} / \mathrm{km}^{2} /$ year $(\mathrm{YN}-6)>4891 \mathrm{t} / \mathrm{km}^{2} /$ year $(\mathrm{YN}-1)$.

\subsection{Water erosion under different crop species and field treatments}

Specific crop species coupled with different field treatments serve key functions in the consequences of surface runoff and erosion generation under gently sloping conditions. Based on the designed field experiments (Table 1) and measured soil hydrological data, RC and EM among different crop species and field treatments were calculated and analyzed (Fig. 2).

Fig. 2 shows that water erosion rates differed across various crop species. Irrespective of the specific field treatment, potato (Solanum tuberosum $\mathrm{L}$.) had the most severe runoff and erosion rates, with a mean RC of $26.87 \%$ and a mean EM of $9197 \mathrm{t} / \mathrm{km}^{2} /$ year. Given that potato is one of the key cash crops and is cultivated by almost every family in Dingxi, the crop has a widespread economic effect on local communities, such that more attention should be paid to this issue. Flax (Linum usitattissimum L.) exhibited the second most severe EM (7812 t/ $\mathrm{km}^{2} /$ year) and the third highest RC (23.31\%), whereas wheat (Triticum aestivum Linn.) had the third highest EM (7664 t/ $\mathrm{km}^{2} /$ year) and second highest RC (23.67\%). The values of RC decreased in the orderpea (Pisum sativum Linn.), haricot (Dolichos Lablab L.), and E. milvetch; conversely, the values of EM decreased in the order haricot, pea, and E. milvetch. Fallow land had the lowest RC and EM among the aforementioned crop species, with a mean RC of $13.59 \%$ and a mean EM of $2419 \mathrm{t} / \mathrm{km}^{2} /$ year.

Additionally, soil and water loss under different crop species increased in complexity with field treatments (Fig. 2). In general, such treatments played key roles in reducing or accelerating the consequences of water erosion. Based on the results shown in Fig. 2, field treatments in wheat and pea plots were effective at altering the magnitude of runoff and soil loss. Minimum tillage, contour cultivation, and collocation with shrub species (e.g., sea buckthorn) and stiletto were powerful methods for reducing water erosion, whereas cultivation with traditional up-down directions could aggravate it. Specifically, with the same crop species, the erosion reduction effects of the aforementioned field treatments increased in the following order: wheat + seabuckthorn, wheat + contour cultivation, wheat + stiletto, wheat + minimum tillage, and wheat + up-down cultivation. All RC and EM values remained far higher than those in the fallow and E. milvetch plots.

\subsection{Water erosion consequences across different CRTs}

CRTs refer to the temporal changes in crop species on the same settled field in consecutive plantings and recurring sequences based on agronomic rules (Thenail et al., 2009). The mean values of RC and EM under the seven CRTs were calculated and analyzed (Fig. 3) to 
a

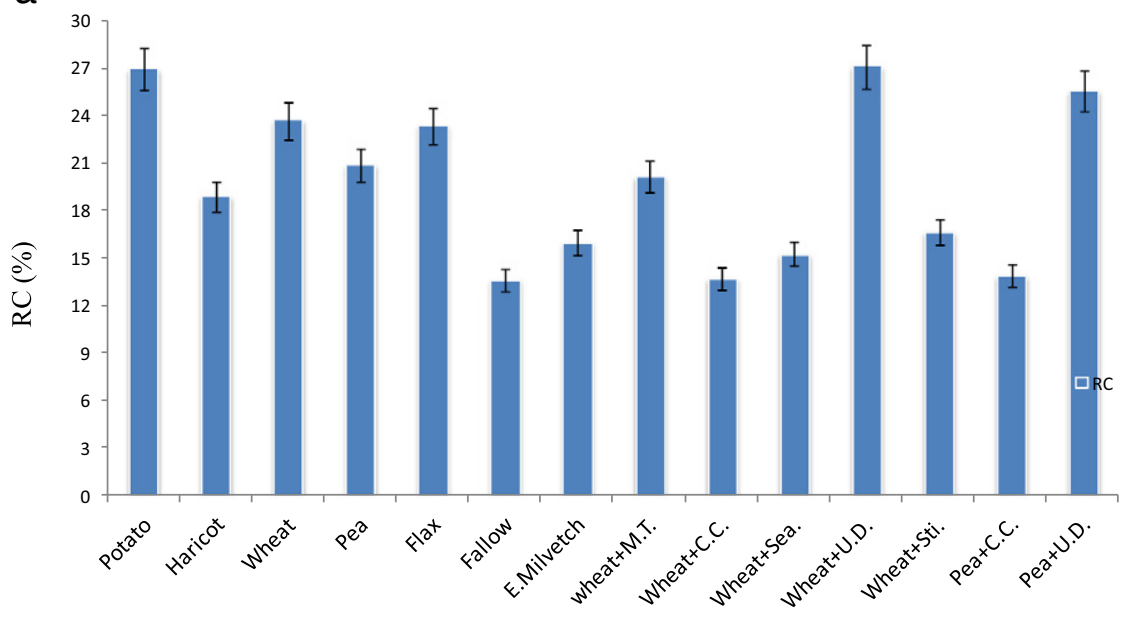

Crop species and field treatments

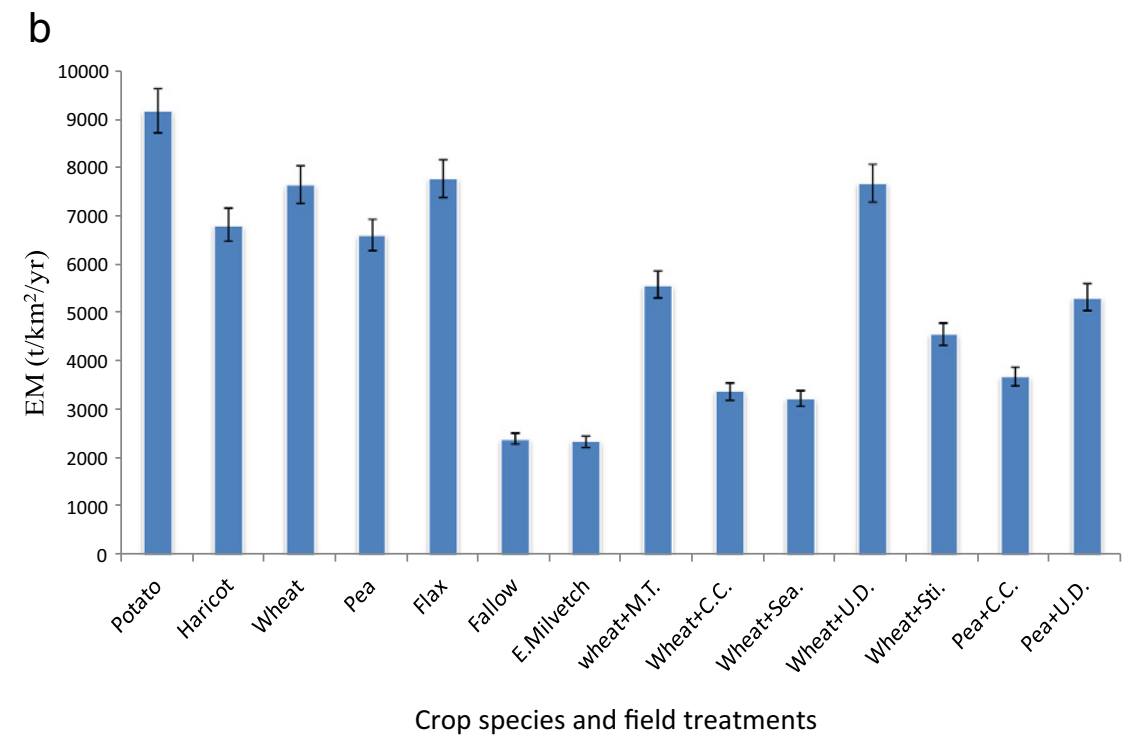

Note: M.T., Sea., Sti., C.C., and U.D. are minimum tillage, sea buckthorn, stiletto, contour cultivation and up-down cultivation, respectively.

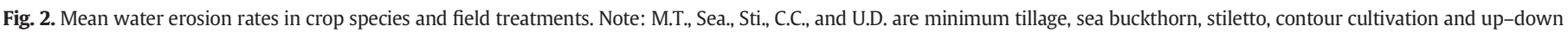
cultivation, respectively.

compare the degrees of soil erosion and runoff loss under different CRTs from a statistical point of view.

Fig. 3 shows that the lowest values of soil and water loss occurred in CRT-7 (consecutively planted in E. milvetch) and CRT-2 (where field treatments such as contour cultivation and minimum tillage were followed by fallow in the last 4 years). The RC values of these two CRTs were very similar ( $15.9 \%$ and $16.5 \%$, respectively), whereas EM under CRT-7 (2365 t/ $/ \mathrm{km}^{2} /$ year) was significantly lower than that under CRT-2 (4304 t/ $/ \mathrm{km}^{2} /$ year). The highest RC and EM values of $24.15 \%$ and $8333 \mathrm{t} / \mathrm{km}^{2} /$ year, respectively, appeared in CRT-4. Soil loss and water loss under the other four major CRTs were more complicated and uncertain. The second highest RC was in CRT-1 (23.2\%), followed by CRT-6 (23.0\%), CRT-5 (22.1\%), and CRT-3 (21.4\%). The EM values decreased in the order CRT-6 (7828 t/ $\mathrm{km}^{2} /$ year), CRT-1 (7694 t/ $\mathrm{km}^{2} /$ year), CRT-5 (6755 t/ $/ \mathrm{km}^{2} /$ year), and CRT-3 (6526 t/ $/ \mathrm{km}^{2} /$ year).
Fig. 4 shows that the annual RC and EM values varied highly across each year for each CRT. The values were affected by many factors: annual rainfall features, crop species planted in certain years, and specific field treatments in certain plots. The result indicates that multiple meteorological and environmental factors collectively contributed to total erosion. Nevertheless, the annual values of RC and EM exhibited no clear trend of change for CRT-1, CRT-3, CRT4 , CRT-5, and CRT-6; instead, the values varied irregularly throughout the eight hydrological years. The most interesting phenomenon is the two decreasing trend lines of CRT-7 (where E. milvetch was grown continuously for years) and CRT-2 (wheat/pea/wheat + minimum tillage/benne/fallow/fallow/fallow/fallow; see Fig. 4). The two lines show that RC and EM decreased markedly as the years progressed, whereas no similar trend was observed in the other CRTs. Within the two mentioned lines, the trends for RC and EM values were more substantial in CRT-2 than in CRT-7 for the 

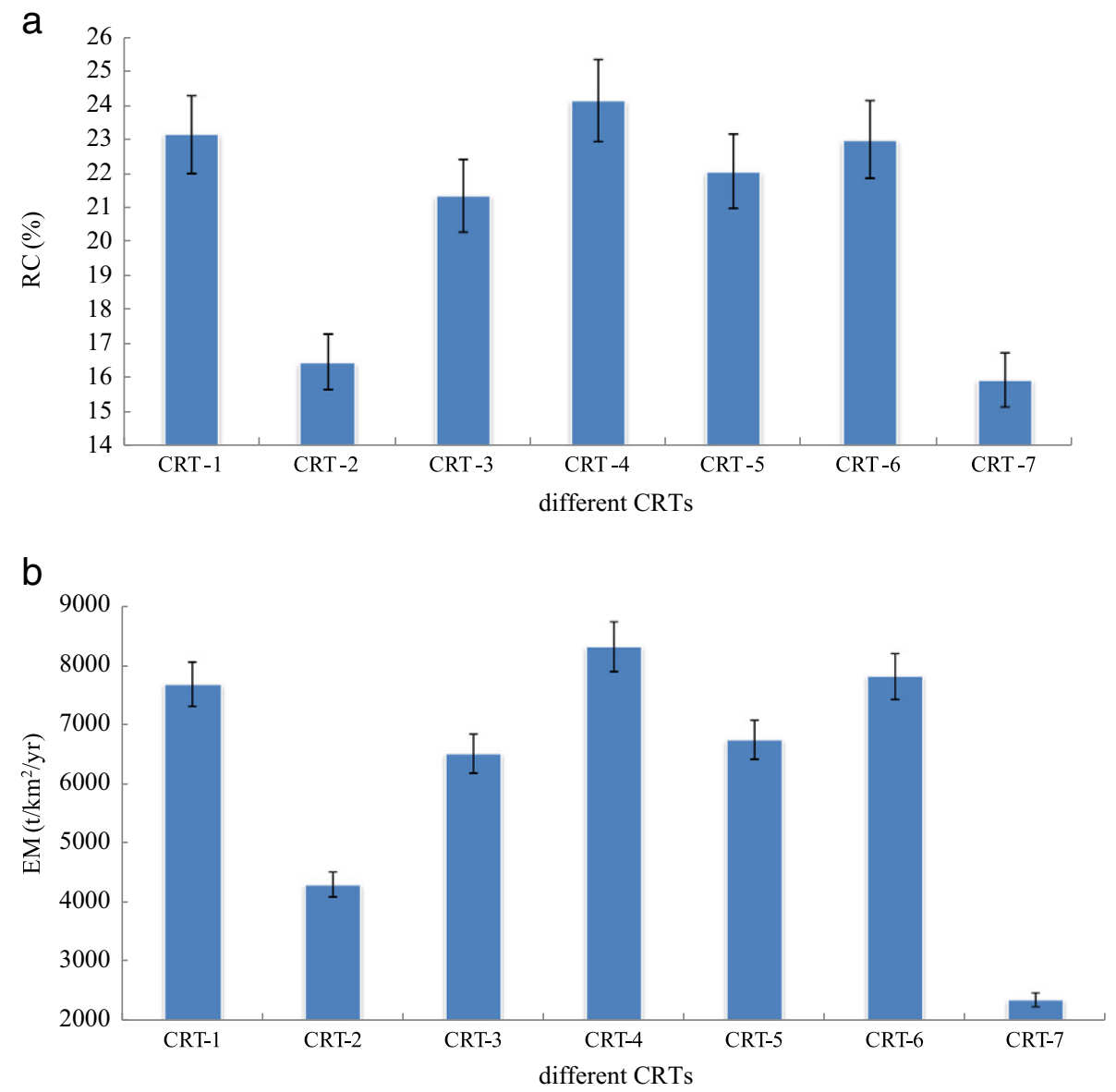

Fig. 3. Soil and water loss under CRTs.

first 4 to 5 years, after which the rates of surface runoff and soil erosion in CRT-2 became slightly lower than those of CRT-7.

\section{Discussion}

\subsection{Effects of temporal rainfall features on water erosion}

Our results showed that water erosion rates varied highly with changes in rainfall features even with the same planted crop species (Fig. 4). High rainfall intensity events with relatively long durations induced higher erosion rates (Table 2). The highest values of RC and EM both appeared in YN-7, followed by YN-2, YN-3, and YN-5. The lowest rates of runoff and soil erosion appeared in YN-6 (Table 1). The mean annual RC and EM exhibited a similar trend across most years, except in YN-1, YN-4, and YN-8 (Table 1). This dynamic trend is very close to the temporal distribution of erosive rainfall and related variables (Table 2), indicating the significant function of annual rainfall features in dominating water erosion. Furthermore, Pearson correlation analysis also confirmed that different rainfall variables such as rainfall depth, duration, and intensity have different correlations with water erosion, which indicates that these key variables may serve different functions in runoff and soil erosion (Tables 3 and 4). For example, rainfall depth, rather than $\mathrm{MI}_{30}$, has a more significant correlation with RC, followed by that of mean intensity, whereas $\mathrm{MI}_{30}$ has a significantly closer relation with EM than rainfall depth. Rainfall duration less strongly correlated with water erosion compared with other rainfall variables.

Other studies support our results (Berger et al., 2010; de Lima and Singh, 2002). For example, the shape of the runoff hydrograph and the water erosion consequences are determined by local rainfall regimes and storm patterns (de Lima and Singh, 2002; Thomas et al., 2011). The spatiotemporal heterogeneity and variability of natural rainfall serve key functions in the generation of water erosion (Morin et al., 2006; Nearing et al., 2005). Shipitalo and Edwards (1998) also declared that, irrespective of the tillage practice, infrequent severe rainstorms caused most of the soil loss. In the semiarid region of northern Shaanxi Province, studies have certified that surface runoff volume and velocity under sloping conditions are derived mainly from stochastic storms, whereas low-intensity precipitation contributes to infiltration (Fan et al., 2010). Liu (1999) reported that more than 70\% of the erosion events in the Loess Plateau were induced by a limited number of heavy rainstorms. In central Ohio in the United States, thunderstorms occur on approximately 40 days each year. Such short-duration storms caused most of the soil erosion (Stavi and Lal, 2011). Based on longterm field monitoring and clustering methodology, water erosion in the loess area was found to be dominated by "high intensity, short duration, and high frequency" rainfall regimes and some extreme events (Wei et al., 2007, 2009).

\subsection{Effects of crop species and field treatments on water erosion}

In this study, the specific consequences of water erosion varied significantly among different crop species (Table 1 and Fig. 4). The variation indicates that specific crop species and field treatments serve key functions in runoff generation and erosion variability. Soil erosion risks can be reduced to a tolerable extent through proper crop selection and efficient field management (Baets et al., 2011). Based on our research, potatoes had the highest water-erosion risk under sloping conditions, whereas the intercropping type (e.g., wheat + sea buckthorn) 
a

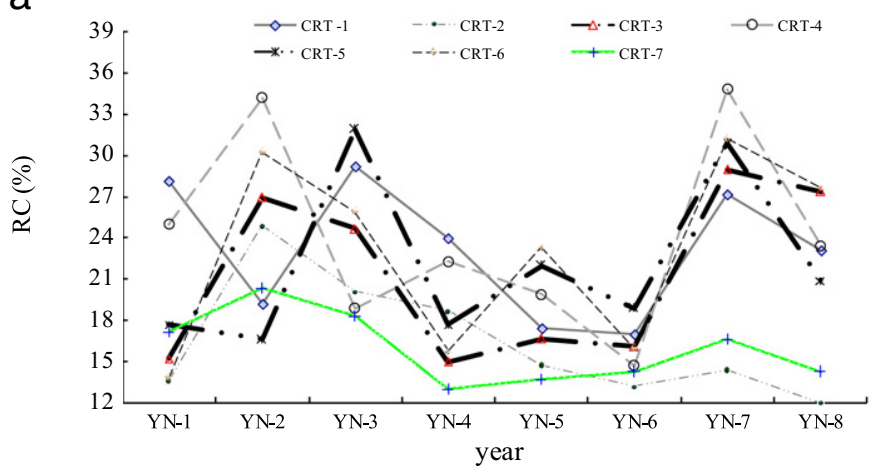

b

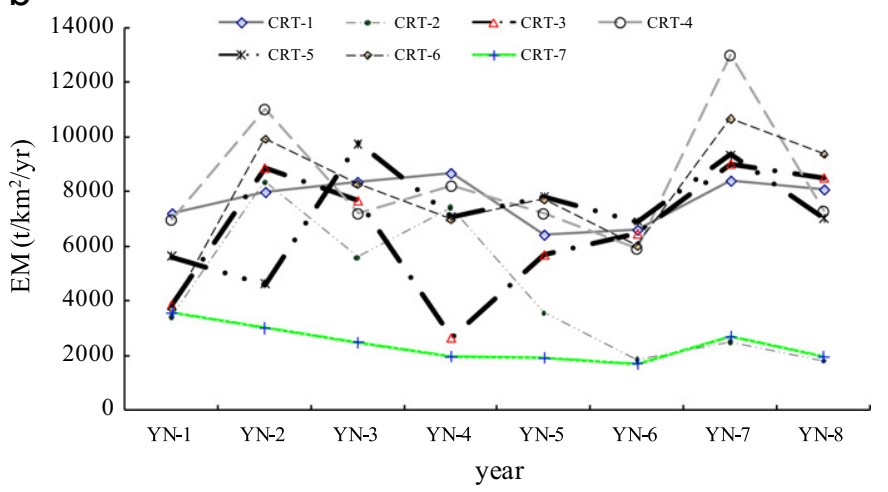

Fig. 4. Soil and water loss under CRTs in different years.

exhibited the lowest degree of soil erosion, making it notably much better than planted wheat with stiletto supplements.

Furthermore, supplemental field treatments such as minimum tillage (e.g., where wheat was cultivated in CRT-2 in YN-3), sloping stiletto (CRT-5 in YN-2), and intercropping measures (CRT-3 in YN-4) were valuable measures for reducing the potential risks of water erosion in our study (Table 1). Contour cultivation was also reconfirmed as a more effective conservation measure compared with traditional cultivation in up-and-down slope directions in most cases (Fiener et al., 2011; Wang et al., 2010). Similar conclusions regarding this issue have been drawn from other regions. For example, soil erosion risks were extremely high with tillage and up-and-down planting on slopes (traditional plough tillage) in central Croatia, whereas no tillage (NT) could reduce erosion by $40 \%$ to $65 \%$ compared with plowing upand-down the slope (Basic et al., 2004). In Uruguay, continuous cropping (CC) with conventional tillage (CT) was proven unsustainable because of decreased soil productivity (Fernando et al., 2004). Soil erosion was reduced by more than six times with NT in CC and by almost three times with crop-pasture species alteration compared with CC using CT. In Switzerland, approximately $88 \%$ of soil erosion occurred on plowed land, followed by non-plowed land (9\% of soil erosion), and strip-tilled or contour-cultivated land ( $2 \%$ of soil erosion) (Prasuhn, 2012).

Potato (Solanum tuberosum L.) is a major economic crop species that is widely cultivated in this area. Based on local government policy, the potato plantation industry is one of the chief mainstays of local financial revenue and farmer income. The most recent 1-year data indicate that more than $2000 \mathrm{~km}^{2}$ of potatoes were planted in Dingxi in 2010. However, potato cultivation on slopes caused more severe erosion compared with that of other crop species. The severe erosion deteriorated soil productivity and ultimately decreased potato yields. In central Europe, Auerswald et al. (2006) also stated that potatoes induce the highest soil erosion risk among the major crop species. Long-term field experiments in the western part of Lithuania (Jankauskas and Jankauskiene, 2003) indicated far higher water erosion rates with potatoes $\left(4440 \mathrm{t} / \mathrm{km}^{2} /\right.$ year to $18,620 \mathrm{t} / \mathrm{km}^{2} /$ year) than with wither rye $\left(540 \mathrm{t} / \mathrm{km}^{2} /\right.$ year to1700 t/ $\mathrm{km}^{2} /$ year) or spring barley $\left(1800 \mathrm{t} / \mathrm{km}^{2} /\right.$ year to $6280 \mathrm{t} / \mathrm{km}^{2} /$ year). A similar phenomenon was observed in Switzerland. Prasuhn (2012) found that the highest soil loss was observed for potatoes ( $287 \mathrm{t} / \mathrm{km}^{2} /$ year), accounting for more than $50 \%$ of the soil loss in summer, followed by fallow $\left(106 \mathrm{t} / \mathrm{km}^{2} /\right.$ year $)$, winter wheat (105 t/ $\mathrm{km}^{2} /$ year), maize $\left(44 \mathrm{t} / \mathrm{km}^{2} /\right.$ year), rape seed (39 t/ $\mathrm{km}^{2} /$ year), and sugar beet $\left(27 \mathrm{t} / \mathrm{km}^{2} /\right.$ year $)$. The vulnerability of potatoes to three key types of erosion accounts for this: soil erosion by water, tillage erosion, and harvest erosion (Tiessen et al., 2007). Therefore, large-scale potato plantations with traditional up-anddown cultivation on slopes are not recommended for the reduction of soil water loss from sloping farmlands. Effective and supplemental

Table 3

Pearson correlation between rainfall variables and runoff.

\begin{tabular}{|c|c|c|c|c|c|c|c|c|c|}
\hline & & \multicolumn{2}{|c|}{ Rainfall depth } & \multicolumn{2}{|c|}{ Rainfall duration } & \multicolumn{2}{|c|}{ Mean intensity } & \multicolumn{2}{|l|}{$\mathrm{MI}_{30}$} \\
\hline & & $\begin{array}{l}\text { Pearson } \\
\text { correlation }\end{array}$ & $\begin{array}{l}\text { Significance } \\
\text { (2-tailed) }\end{array}$ & $\begin{array}{l}\text { Pearson } \\
\text { correlation }\end{array}$ & $\begin{array}{l}\text { Significance } \\
\text { (2-tailed) }\end{array}$ & $\begin{array}{l}\text { Pearson } \\
\text { correlation }\end{array}$ & $\begin{array}{l}\text { Significance } \\
\text { (2-tailed) }\end{array}$ & $\begin{array}{l}\text { Pearson } \\
\text { correlation }\end{array}$ & $\begin{array}{l}\text { Significance } \\
\text { (2-tailed) }\end{array}$ \\
\hline \multirow[t]{3}{*}{ CRT-1 } & P1 & $0.698 a$ & 0.000 & -0.237 & 0.313 & $0.300 a$ & 0.000 & $0.647 \mathrm{~b}$ & 0.005 \\
\hline & $\mathrm{P} 2$ & $0.709 a$ & 0.000 & -0.251 & 0.267 & $0.383 b$ & 0.002 & $0.689 a$ & 0.001 \\
\hline & P3 & $0.707 a$ & 0.000 & -0.273 & 0.202 & $0.373 b$ & 0.004 & $0.684 b$ & 0.002 \\
\hline \multirow[t]{3}{*}{ CRT-2 } & P4 & $0.347 \mathrm{c}$ & 0.021 & -0.167 & 0.219 & $0.149 \mathrm{~b}$ & 0.008 & $0.350 \mathrm{c}$ & 0.024 \\
\hline & P5 & $0.352 b$ & 0.008 & -0.158 & 0.244 & $0.147 c$ & 0.019 & $0.329 c$ & 0.011 \\
\hline & P6 & $0.356 c$ & 0.023 & -0.186 & 0.170 & $0.134 \mathrm{c}$ & 0.012 & $0.283 c$ & 0.027 \\
\hline \multirow[t]{3}{*}{ CRT-3 } & P7 & $0.636 b$ & 0.008 & -0.162 & 0.157 & $0.222 b$ & 0.002 & $0.693 c$ & 0.012 \\
\hline & P8 & $0.649 \mathrm{c}$ & 0.011 & -0.156 & 0.251 & $0.230 \mathrm{c}$ & 0.017 & $0.646 b$ & 0.008 \\
\hline & P9 & $0.642 \mathrm{~b}$ & 0.005 & -0.179 & 0.166 & $0.243 b$ & 0.006 & $0.671 \mathrm{c}$ & 0.011 \\
\hline \multirow[t]{3}{*}{ CRT-4 } & P10 & $0.767 a$ & 0.000 & -0.285 & 0.272 & $0.466 a$ & 0.000 & $0.736 a$ & 0.001 \\
\hline & P11 & $0.789 a$ & 0.000 & -0.279 & 0.322 & $0.431 \mathrm{~b}$ & 0.007 & $0.750 \mathrm{~b}$ & 0.003 \\
\hline & P12 & $0.793 a$ & 0.000 & -0.282 & 0.317 & $0.456 a$ & 0.000 & $0.737 a$ & 0.001 \\
\hline \multirow{3}{*}{ CRT-5 } & P13 & $0.662 c$ & 0.011 & -0.174 & 0.200 & $0.237 \mathrm{~b}$ & 0.004 & $0.697 b$ & 0.007 \\
\hline & P14 & $0.671 b$ & 0.009 & -0.183 & 0.254 & $0.236 c$ & 0.011 & $0.688 \mathrm{c}$ & 0.011 \\
\hline & P15 & $0.685 c$ & 0.014 & -0.177 & 0.293 & $0.238 b$ & 0.006 & $0.684 b$ & 0.008 \\
\hline \multirow[t]{3}{*}{ CRT-6 } & P16 & $0.683 a$ & 0.001 & -0.194 & 0.201 & $0.284 a$ & 0.001 & $0.656 b$ & 0.010 \\
\hline & P17 & $0.683 a$ & 0.000 & -0.181 & 0.265 & $0.295 c$ & 0.027 & $0.674 a$ & 0.000 \\
\hline & P18 & $0.699 a$ & 0.000 & -0.184 & 0.228 & $0.289 b$ & 0.005 & $0.676 b$ & 0.006 \\
\hline \multirow{3}{*}{ CRT-7 } & P19 & $0.289 \mathrm{c}$ & 0.035 & -0.118 & 0.244 & $0.132 \mathrm{c}$ & 0.013 & $0.233 c$ & 0.038 \\
\hline & P20 & $0.291 \mathrm{c}$ & 0.041 & -0.124 & 0.216 & $0.123 c$ & 0.015 & $0.236 c$ & 0.045 \\
\hline & P21 & $0.278 \mathrm{c}$ & 0.038 & -0.126 & 0.226 & $0.110 \mathrm{c}$ & 0.020 & $0.263 c$ & 0.041 \\
\hline
\end{tabular}

Note: $a, b$, and c indicate that correlation is significant at the $0.001,0.01$, and 0.05 levels (2-tailed), respectively. 
Table 4

Pearson correlation between rainfall variables and sediment yield.

\begin{tabular}{|c|c|c|c|c|c|c|c|c|c|}
\hline \multirow[t]{3}{*}{ CRTs } & \multirow[t]{3}{*}{ Plot } & \multicolumn{8}{|c|}{ Rainfall variables } \\
\hline & & \multicolumn{2}{|c|}{ Rainfall depth } & \multicolumn{2}{|c|}{ Rainfall duration } & \multicolumn{2}{|c|}{ Mean intensity } & \multicolumn{2}{|l|}{$\mathrm{MI}_{30}$} \\
\hline & & $\begin{array}{l}\text { Pearson } \\
\text { correlation }\end{array}$ & $\begin{array}{l}\text { Significance } \\
\text { (2-tailed) }\end{array}$ & $\begin{array}{l}\text { Pearson } \\
\text { correlation }\end{array}$ & $\begin{array}{l}\text { Significance } \\
\text { (2-tailed) }\end{array}$ & $\begin{array}{l}\text { Pearson } \\
\text { correlation }\end{array}$ & $\begin{array}{l}\text { Significance } \\
\text { (2-tailed) }\end{array}$ & $\begin{array}{l}\text { Pearson } \\
\text { correlation }\end{array}$ & $\begin{array}{l}\text { Significance } \\
\text { (2-tailed) }\end{array}$ \\
\hline \multirow[t]{3}{*}{ CRT-1 } & P1 & $0.518 a$ & 0.001 & -0.342 & 0.213 & $0.524 a$ & 0.000 & $0.757 a$ & 0.000 \\
\hline & P2 & $0.499 b$ & 0.004 & -0.317 & 0.275 & $0.533 b$ & 0.004 & $0.779 a$ & 0.001 \\
\hline & P3 & $0.577 \mathrm{~b}$ & 0.002 & -0.299 & 0.307 & $0.613 b$ & 0.008 & $0.784 a$ & 0.001 \\
\hline \multirow[t]{3}{*}{ CRT-2 } & $\mathrm{P} 4$ & $0.236 c$ & 0.041 & -0.156 & 0.321 & $0.310 \mathrm{~b}$ & 0.004 & $0.411 c$ & 0.024 \\
\hline & P5 & $0.275 c$ & 0.028 & -0.161 & 0.314 & $0.321 \mathrm{c}$ & 0.015 & $0.429 c$ & 0.011 \\
\hline & P6 & $0.264 c$ & 0.034 & -0.148 & 0.231 & $0.297 c$ & 0.021 & $0.423 c$ & 0.017 \\
\hline \multirow[t]{3}{*}{ CRT-3 } & P7 & $0.421 \mathrm{c}$ & 0.018 & -0.167 & 0.198 & $0.477 b$ & 0.004 & $0.589 \mathrm{a}$ & 0.001 \\
\hline & P8 & $0.443 c$ & 0.013 & -0.169 & 0.201 & $0.483 b$ & 0.009 & $0.590 \mathrm{~b}$ & 0.004 \\
\hline & P9 & $0.442 b$ & 0.008 & -0.178 & 0.233 & $0.491 b$ & 0.005 & $0.613 a$ & 0.000 \\
\hline \multirow[t]{3}{*}{ CRT-4 } & P10 & $0.556 \mathrm{~b}$ & 0.007 & -0.378 & 0.102 & $0.666 a$ & 0.000 & $0.806 a$ & 0.001 \\
\hline & P11 & $0.563 a$ & 0.001 & -0.383 & 0.113 & $0.631 b$ & 0.004 & $0.750 \mathrm{~b}$ & 0.003 \\
\hline & P12 & $0.593 b$ & 0.004 & -0.382 & 0.120 & $0.696 a$ & 0.000 & $0.817 \mathrm{a}$ & 0.001 \\
\hline \multirow{3}{*}{ CRT-5 } & P13 & $0.467 \mathrm{c}$ & 0.011 & -0.247 & 0.210 & $0.496 \mathrm{~b}$ & 0.004 & $0.628 \mathrm{a}$ & 0.000 \\
\hline & P14 & $0.472 \mathrm{c}$ & 0.014 & -0.286 & 0.242 & $0.517 c$ & 0.011 & $0.636 b$ & 0.007 \\
\hline & P15 & $0.458 c$ & 0.015 & -0.257 & 0.245 & $0.528 b$ & 0.006 & $0.665 a$ & 0.001 \\
\hline \multirow{3}{*}{ CRT-6 } & P16 & $0.494 b$ & 0.006 & -0.287 & 0.289 & $0.514 a$ & 0.001 & $0.711 \mathrm{a}$ & 0.000 \\
\hline & P17 & $0.487 \mathrm{c}$ & 0.011 & -0.304 & 0.276 & $0.525 b$ & 0.007 & $0.724 a$ & 0.000 \\
\hline & P18 & $0.490 \mathrm{a}$ & 0.000 & -0.299 & 0.285 & $0.589 \mathrm{~b}$ & 0.003 & $0.736 a$ & 0.001 \\
\hline \multirow[t]{3}{*}{ CRT-7 } & P19 & $0.202 c$ & 0.047 & -0.138 & 0.312 & $0.245 c$ & 0.018 & $0.318 c$ & 0.031 \\
\hline & P20 & $0.191 \mathrm{c}$ & 0.039 & -0.145 & 0.341 & $0.259 c$ & 0.017 & $0.326 c$ & 0.033 \\
\hline & P21 & 0.210 & 0.052 & -0.147 & 0.296 & $0.254 c$ & 0.024 & $0.363 c$ & 0.024 \\
\hline
\end{tabular}

Note: $a, b$, and c indicate that correlation is significant at the $0.001,0.01$, and 0.05 levels (2-tailed), respectively.

field measures such as terrace construction, mulching, and contour cultivation should be strictly implemented in sloping potato farmlands.

\subsection{Effects of CRTS on consequences of water erosion}

Water erosion rates under different CRTs differ (Prasuhn, 2012; Table 1 and Fig. 3). Based on our research, the highest erosion rates occurred in CRT-4, CRT-1, and CRT-6, whereas the lowest values appeared in CRT-2 and CRT-7. As mentioned, the differences are mainly accounted for by the specific crop species and field treatments used in certain seasons and years. For example, different CRTs and plant succession stages may markedly affect the risks and variations of runoff generation and erosion potential (Liu, 1999; Stevens et al., 2009). Moreover, our study confirmed that traditional cultivation on sloping land and simple crop-rotation management without other effective measures cannot significantly reduce erosion and water loss. The related erosion moduli in such CRTs (e.g., CRT-4, CRT-1, and CRT-6) were significantly higher than those for rotation types with intercropping or surface stiletto measures (e.g., CRT-3 and CRT-5). The effect of crop rotation on water erosion reduction has been studied extensively in many countries worldwide. For example, a typical case study was conducted in Lithuania, where grass-grain crop rotations ( $>50 \%$ grass) decreased the total soil loss on arable slopes by $77 \%$ to $81 \%$, whereas grain-grass rotation only decreased rates by $21 \%$ to $24 \%$ (Jankauskas and Jankauskiene, 2003).

Consecutive plant succession without human disturbance can be considered as a special CRT and is an effective measure to reduce water erosion hazards (Table 1; Figs. 3 and 4). For example, severe water erosion in CRT-2 was observed in the first several years of the study because of the traditional cultivation, and simple CRTs seemed ineffective for erosion reduction. After land conversion (for instance, sloping croplands were abandoned and left fallow in a natural succession from YN-5 to YN-8), however, water erosion decreased markedly over time, and related soil-water conservation measures improved (Fig. 4). In CRT-7, E. milvetch was established in YN-1 and then left to grow. The annual mean RC and EM decreased gradually over time. Other studies have also found that soil erosion decreases with plant succession. For instance, Jankauskas and Jankauskiene (2003) declared that perennial grasses with higher plant coverage completely prevented water erosion. In Shenmu City, northern Shaanxi, natural grass growth is better than human-cultivated plants with high water use, such as alfalfa, from any erosion control or soil-water improvement perspective (Fan et al., 2010). Wei et al. (2007) found that runoff and erosion under sea buckthorn were severe during the first 3 to 4 years after plantation and then decreased sharply and stabilized at a very low level. One of the major reasons for decreases in soil erosion with plant succession is the increase in soil aggregate stability and anti-shearing capability (Fernando et al., 2004). Dense and fibrous grass root systems also promote soil aggregation and improve erosion control (Novara et al., 2013), as does soil organic matter, which can be improved to enhance land productivity (Miglierena et al., 2000).

\subsection{Coupling effects of rainfall, crop species, and CRTs on water erosion}

Based on our research, the coupling effects among rainfall, crop species, and CRTs on runoff and soil erosion became more complicated than those under similar conditions of rainfall or CRTs (Figs. 3 and 4; Tables 3 and 4). For example, although rainfall is a key driver behind various levels and magnitudes of water erosion (Berger et al., 2010; de Lima and Singh, 2002; Thomas et al., 2011; Wei et al., 2009), its effect on RC and EM is also dependent on specific surface features such as crop coverage and field management, such that the response and sensitivity of water erosion are not only affected by different rainfall variables but also determined by other human and environmental factors (Berger et al., 2010; Fiener et al., 2011; Shi et al., 2010). Correlations between water erosion and rainfall variables vary (Tables 3 and 4), and values of the Pearson correlation index decreased in the order CRT-4, CRT-1, CRT-6, CRT-5, CRT-3, CRT-2, and CRT-1, which is in agreement with erosion rates in the related CRTs (Fig. 3 ). This finding implies that more severe water erosion results in increased frangibility of surface features and increased sensitivity to rainfall.

On the other hand, different field conditions and surface cover features, including crop species, rotation, cultivation direction, and plant succession stages, may all serve various functions in accelerating or weakening the risks and potentials of soil erosion (Carling et al., 2001; Freebairn et al., 1993; Lafond et al., 2006; Stavi and Lal, 2011; Wang et al., 2010). In this study, for example, severe soil-water loss from sloping land was induced by potato cultivation, followed by flax (a very traditional crop species used for making edible oil), whereas 
lands in fallow or natural succession reduced the severity of water erosion (Fig. 3). Under similar rainfall conditions, soil-water loss differed from CRT management variations (e.g., Fig. 3). As a result, erosive rainstorms coupled with crops that are poorly resistant to erosion (e.g., potatoes and flaxes) and traditional up-down slope cultivation significantly accelerated water erosion rates.

Furthermore, sloping locations $\left(10^{\circ}\right.$ to $20^{\circ}$ gradients) experienced water erosion far higher than the tolerable criterion $\left(<1000 \mathrm{t} / \mathrm{km}^{2} /\right.$ year$)$ established by the Ministry of Water Resource in 1996 (Wei et al., 2007), even with the implementation of different CRTs and effective field treatments. This phenomenon indicates that water erosion on slopes with gradients steeper than $20^{\circ}$ significantly contributed to total soil-water loss. Similar conclusions have been drawn by other scientists (Fu et al., 2011). However, the "Grain for Green" project only specified sloping farmlands that have gradients exceeding $25^{\circ}$, so sloping farmlands at lower gradients were neglected to some extent. Therefore, more attention should be directed toward water erosion on slopes with low gradients. More powerful measures, new effective field treatment technologies, and systematic studies should be conducted to construct a more sustainable eco-environment for the region.

\section{Conclusions and implications}

In this study, 8 years of water erosion data under seven CRTs from a low-gradient (less than $25^{\circ}$ ) loess hillslope in NW China were analyzed, and several major findings were highlighted. The results showed that soil and water loss on slopes with gradients lower than $20^{\circ}$ remained far higher than the acceptable criterion, even after different CRTs and field treatments were implemented. Considerable attention should be directed toward this situation. Potato cultivation on sloping land caused the highest water erosion compared with other crops (e.g., wheat and legume). Given that potato farming is a major economic crop industry, potato should either be cultivated on terraced lands rather than under sloping conditions or other supplemental measures should be conducted. Furthermore, water erosion under CRTs with necessary supplemental measures such as surface stiletto, chisel plowing, contour cultivation, crop-shrub intercropping, and farmland abandonment can contribute to water erosion control and is thus believed to be advantageous for soil-water conservation. Finally, water erosion rates under different CRTs are markedly affected by the occurrence, characteristics, and distribution of rain events, especially the ratio and intensity of erosive rainfall.

Our findings have crucial implications for erosion control, slope stability, ecosystem restoration, and land productivity in many similar regions of the world. In particular, the magnitude of water erosion on gentle slopes cannot be subjectively underestimated, especially when these slopes suffer from extreme rainfall events. Owing to the positive and powerful role in water erosion reduction of natural plant succession by land closure or farmland abandonment, such gentle slopes should be strictly protected without surface disturbance. When crop cultivation and other important agricultural activities are necessary on such slopes, effective CRTs and supplemental field treatments (e.g., ground drilling, mulching, or even land terracing) are strongly encouraged. More importantly, we strongly recommend that the government adjust the current slope criterion of a $25^{\circ}$ gradient in the "Grain for Green" project in loess and other similar regions.

\section{Acknowledgements}

This research was supported by the National Natural Science Foundation of China $(41390462 ; 41371123)$. Our sincere thanks are conferred to the Dingxi Institute of Soil and Water Conservation for data collection and cooperation in the field.

\section{References}

Albergel, J., Collinet, J., Pe'pin, Y., Nasri, S., Boufaroua, M., Droubi, A., Merzouk, A., 2005. Sediment budgets on hill reservoirs of small catchments in North Africa and the Middle East. Iash 291 (1), 323-331.

Auerswald, K., Gerl, G., Kainz, M., 2006. Influence of cropping system on harvest erosion under potato. Soil Tillage Res. 89, 22-34.

Baets, S.D., Poesen, J., Serlet, J.M.L., 2011. Cover crops and their erosion-reducing effects during concentrated flow erosion. Catena 85, 237-244.

Basic, F., Kisic, I., Mesic, M., Nestroy, O., Butorac, A., 2004. Tillage and crop management effects on soil erosion in central Croatia. Soil Tillage Res. 78, 197-206.

Berger, C., Schulze, M., Rieke-Zapp, D., Schlunegger, Fritz, 2010. Rill development and soil erosion: a laboratory study of slope and rainfall intensity. Earth Surf. Process. Landf. 35, 1456-1467.

Carling, P.A., Irvine, B.J., Hill, A., Wood, M., 2001. Reducing sediment inputs to Scottish streams: a review of the efficacy of soil conservation practices in upland forestry. Sci. Total Environ. 265, 209-227.

Chen, L.D., Wei, W., Fu, B.J., Lü, Y.H., 2007. Soil and water conservation on the loess plateau in China: review and prospective. Prog. Phys. Geogr. 31, 389-403.

Chen, L.D., Wang, J.P., Wei, W., Fu, B.J., Wu, D.P., 2010. Effects of landscape restoration on soil water storage and water use in the Loess Plateau Region, China. For. Ecol. Manag. 259, 1291-1298.

de Lima, J.L.M.P., Singh, V.P., 2002. The influence of the pattern of moving rainstorms on overland flow. Adv. Water Resour. 25, 817-828.

Fan, J., Shao, M.A., Wang, Q.J., Scott, B.J., Klaus, R., Cheng, X.R., Fu, X.L., 2010. Toward sustainable soil and water resources use in China's highly erodible semi-arid loess plateau. Geoderma 155, 93-100.

FAO-UNESCO, 1974. Soil map of the world (1:5000 000). Food and agriculture organization of the United Nations, UNESCO, Paris.

Fernando, G.P., Ernst, O., Guillermo, S.P., Terra, J.A., 2004. Integrating no-till into croppasture rotations in Uruguay. Soil Tillage Res. 77, 1-13.

Fiener, P., Auerswald, K., Van Oost, K., 2011. Spatio-temporal patterns in land use and management affecting surface runoff response of agricultural catchments-a review. Earth Sci. Rev. 106, 92-104.

Freebairn, D.M., Loch, R.J., Cogle, A.L., 1993. Tillage methods and soil and water conservation in Australia. Soil Tillage Res. 27, 303-325.

Fu, B.J., 1989. Soil erosion and its control in the Loess Plateau of China. Soil Use Manag. 5, $76-82$

Fu, B.J., Liu, Y., Lü, Y.H., He, C.S., Zeng, Y., Wu, B.F., 2011. Assessing the soil erosion control service of ecosystems change in the Loess Plateau of China. Ecol. Complex. 8, 284-293.

He, J., Li, H.W., Wang, X.Y., McHugh, A.D., Li, W.Y., Gao, H.W., Kuhn, N.J., 2007. The adoption of annual subsoiling as conservation tillage in dryland maize and wheat cultivation in northern China. Soil Tillage Res. 94, 493-502.

Huang, M.B., Shao, M.A., Zhang, L., Li, Y.S., 2003. Water use efficiency and sustainability of different long-tern crop rotation systems in the Loess Plateau of China. Soil Tillage Res. 72, 95-104.

Huang, Y.L., Chen, L.D., Fu, B.J., Huang, Z.L., Gong, J., 2005. The wheat yields and water-use efficiency in the Loess Plateau: straw mulch and irrigation effects. Agric. Water Manag. 72, 209-222.

Jankauskas, B., Jankauskiene, G., 2003. Erosion-preventive crop rotations for landscape ecological stability in upland regions of Lithuania. Agric. Ecosyst. Environ. 95, 129-142.

Kellison, R.C., Young, M.J., 1997. The bottomland hardwood forest of the southern United States. For. Ecol. Manag. 90, 1-115.

Lafond, G.P., May, W.E., Stevenson, F.C., Derksen, F.C., 2006. Effects of tillage systems and rotations on crop production for a thin Black Chernozem in the Canadian Prairies. Soil Tillage Res. 89, 232-245.

Li, F.R., Gao, H.Y., Zhao, H.L., Li, X.Y. 2002. Soil conservation effectiveness and energy efficiency of alternative rotations and continuous wheat cropping in the Loess Plateau of northwest China. Agric. Ecosyst. Environ. 91, 101-111.

Liu, G., 1999. Soil conservation and sustainable agriculture on the Loess Plateau: challenges and prospects. Ambio 28, 663-668.

Malik, R.K., Green, T.H., Brown, G.F., Mays, D., 2000. Use of cover crops in short rotation hardwood plantations to control erosion. Biomass Bioenergy 18, 479-487.

Miglierena, A.M., Iglesias, J.O., Landricini, M.R., Galantini, J.A., Rosell, R.A., 2000. The effects of crop rotation and fertilizationon wheat productivity in the Pampean semiarid region ofArgentina. 1. Soil physical and chemical properties. Soil Tillage Res. 53, 129-135.

Morin, E., Goodrich, D.C., Maddox, R.A., Gao, X.G., Hoshin, V.G., Soroosh, S., 2006. Spatial patterns in thunderstorm rainfall events and their coupling with watershed hydrological response. Adv. Water Resour. 29, 843-860.

Nearing M.A., Jetten, V., Baffaut, C., Cerdan, O., Couturier, A., Hernandez, M., Bissonnais, Y. L., Nichols, M.H., Nunes, J.P., Renschler, C.S., Souchère, V., van Oost, K., 2005. Modeling response of soil erosion and runoff to changes in precipitation and cover. Catena 61, 131-154.

Novara, A., Gristina, L., Mantia, T.L., Rühl, J., 2013. Carbon dynamics of soil organic matter in bulk soil and aggregate fraction during secondary succession in a Mediterranean environment. Geoderma 193-194, 213-221.

Prasuhn, V., 2012. On-farm effects of tillage and crops on soil erosion measured over 10 years in Switzerland. Soil Tillage Res. 120, 137-146.

Raclot, D., Albergel, J., 2006. Runoff and water erosion modelling using WEPP on a Mediterranean cultivated catchment. Phys. Chem. Earth 31, 1038-1047.

Sasal, M.C., Castiglioni, M.G., Wilson, M.G., 2010. Effect of crop sequences on soil properties and runoff on natural-rainfall erosion plots under n o tillage. Soil Tillage Res. 108, 24-29. 
Schiettecatte, W., Ouessar, M., Gabriel, D., Tanghe, S., Heirman, S., Abdelli, F., 2005. Impact of water harvesting techniques on soil and water conservation: a case study on a micro-catchment in southeastern Tunisia. J. Arid Environ. 61, 297-313.

Shi, Z.H., Yan, F.L., Li, L., Li, Z.X., Cai, C.F., 2010. Interrill erosion from disturbed and undisturbed samples in relation to topsoil aggregate stability in red soils from subtropical China. Catena 81 (3), 240-248.

Shi, Z.H., Fang, N.F., Wu, F.Z., Wang, L., Yue, B.J., Wu, G.L., 2012. Soil erosion processes and sediment sorting associated with transport mechanisms on steep slopes. J. Hydrol. 454-455, 123-130.

Shipitalo, M.J., Edwards, W.M., 1998. Runoff and erosion control with conservation tillage and reduced-input practices on cropped watersheds. Soil Tillage Res. 46, 1-12.

Singh, P., Alagarswamy, G., Pathak, P., Wani, S.P., Hoogenboom, G., Virmani, S.M., 1999. Soybean-chickpea rotation on Vertic Inceptisols: I. Effect of soil depth and landform on light interception, water balance and crop yields. Field Crop Res. 63, 211-224.

Stavi, I., Lal, R., 2011. Variability of soil physical quality and erodibility in a water-eroded cropland. Catena 84, 148-155.

Stevens, C.J., Quinton, J.N., Bailey, A.P., Deasy, C., Silgram, M., Jackson, D.R., 2009. The effects of minimal tillage, contour cultivation and in-field vegetative barriers on soil erosion and phosphorous loss. Soil Tillage Res. 106, 145-151.

Thenail, C., Foannon, A., Capitaine, M., Souche`re, V., Mignolet, C., Schermann, N., Di Pietro, F., Pons, Y., Gaucherel, C., Viaud, V., Baudry, J., 2009. The contribution of crop-rotation organization in farms to crop-mosaic patterning at local landscape scales. Agric. Ecosyst. Environ. 131, 207-219.

Thierfelder, C., Wall, P.C., 2009. Effects of conservation agriculture techniques on infiltration and soil water content in Zambia and Zimbabwe. Soil Tillage Res. 105, 217-227.

Thomas, B., Steidl, J., Dietrich, O., Lischeid, G., 2011. Measures to sustain seasonal minimum runoff in small catchments in the mid-latitudes: a review. J. Hydrol. 408, 296-307.
Tiessen, K.H.D., Lobb, D.A., Mehuys, G.R., Rees, H.W., 2007. Tillage erosion within potato production in Atlantic Canada: II. Erosivity of primary and secondary tillage operations. Soil Tillage Res. 95, 320-331.

Turkelboom, F., Poesen, J., Ohler, I., Keer, K.V., Ongprasert, S., Vlassak, K., 1997. Assessment of tillage erosion rates on steep slopes in northern Thailand. Catena 29, 29-44.

Wang, Z.Y., Wang, G.Q., Huang, G.H., 2008. Modeling of state of vegetation and soil erosion over large areas. Int. J. Sediment Res. 23, 181-196.

Wang, T.M., Wu, J.G., Kou, X.J., Oliver, C., Mou, P., Ge, J.P., 2010. Ecologically asynchronous agricultural practice erodes sustainability of the Loess Plateau of China. Ecol. Appl. 20 (4), 1126-1135.

Wei, W., Chen, L.D., Fu, B.J., Huang, Z.L., Wu, D.P., Gui, L.D., 2007. The effect of land uses and rainfall regimes on runoff and soil erosion in the semi-arid loess hilly area, China. J. Hydrol. 335, 247-258.

Wei, W., Chen, L.D., Fu, B.J., Lü, Y.H., Gong, J., 2009. Responses of water erosion to rainfall extremes and vegetation types in a loess semiarid hilly area, NW China. Hydrol. Process. 23, 1780-1791.

Xu, X.L., Ma, K.M., Fu, B.J., Song, C.J., Liu, W., 2008. Relationships between vegetation and soil and topography in a dry warm river valley, SW China. Catena 75, 138-145.

YRCC (Yellow River Conservancy Commission), 1988. Soil and Water Conservation in the Yellow River Valley. Shanghai Educational Press, Shanghai, pp. 7-40.

Zhu, Z.Y., Zhou, H.Y., Xie, J.B., Ouyang, T.P., 2003. A preliminary quantitative analysis of soil erosion intensity on Loess Plateau since the Holocene. J. Soil Water Conserv. 17, 81-83. 